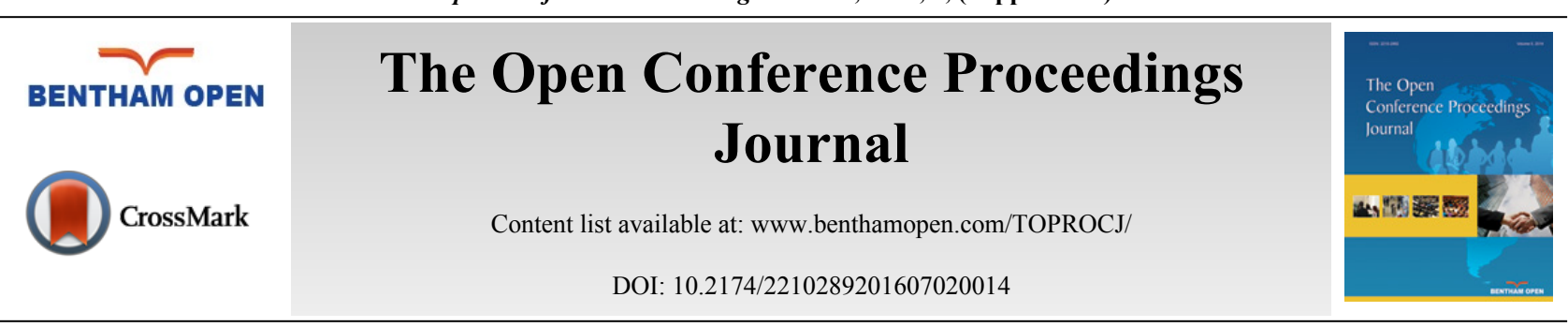

\title{
What About Biofilms on the Surface of Stone Monuments?
}

\author{
Patrick D. Martino* \\ Laboratoire ERRMECe-EA1391, Université de Cergy-Pontoise, 95302 Cergy-Pontoise, France
}

\begin{abstract}
Bacteria can live either as free planktonic cells in bulk solution, or as sessile cells attached to a surface. In addition to their attachment status, sessile bacteria are part of sessile communities termed biofilms. A biofilm can be defined as a microbial community attached to a solid surface composed of cells organized as microcolonies embedded in an organic polymer matrix of microbial origin. Thus, a biofilm is made of microbial cells and extracellular polymeric substances. The biofilm mode of life provides several advantages to microorganisms including resistance to environmental stresses, increased communication and genetic exchange between cells. Microbial biofilm development can be observed on virtually all kinds of stone monuments such as castles, caves, churches/cathedrals, fountains, temples, tombs/catacombs, etc., and can be associated with problems of conservation. Several types of autotrophic and heterotrophic microorganisms are usually observed on stone monuments such as bacteria, fungi, algae and lichens. The European standard EN15898 defines the main general terms used in the field of conservation of cultural property such as alteration, deterioration, weathering, treatment and cleaning. The term biodeterioration is not defined in the EN15898 standard, but can be defined as "any undesirable change in the properties of a material caused by the vital activities of organism". The biodeterioration of stone materials corresponds to an aesthetic action (production of pigments), to a biochemical action (stone dissolution or salt crystallization driven by cell metabolism) and to a physical action (mechanical pressure during growth). This review has two main objectives: to summarize the actual knowledge about basics of microbial colonization and biodeterioration of stone monuments and to realize a quantitative and qualitative analysis of publications in scientific journals on this topic.
\end{abstract}

Keywords: Biocleaning, biofilm, biodeterioration, monument, microorganisms, stone.

\section{DEFINITIONS}

Bacteria can live either as free planktonic cells in bulk solution, or as sessile cells attached to a surface. Antonie van Leuwenhoek was the first scientist to observe sessile bacteria described as aggregates of "animalcules" living at the human tooth surface. In addition to their attachment status, sessile bacteria are part of sessile communities termed biofilms. Since the pioneer study of Antonie van Leuwenhoek, much has been accomplished in understanding the specifics of the biofilm lifestyle. A biofilm can be defined as a microbial community attached to a solid surface composed of cells organised as microcolonies embedded in an organic polymer matrix of microbial origin. Thus, a biofilm is made of water, microbial cells and extracellular polymeric substances (EPS). Many EPS are highly hydrated but most of the water is not directly bound to the EPS [1,2]. EPS comprise both charged (i.e. positive or negative) and uncharged (i.e. neutral) biopolymers. All major classes of biological macromolecules, i.e., polysaccharides, proteins, nucleic acids, and lipids can be part of the biofilm matrix. Although extracellular polysaccharides have been considered for a long time as the major structural components of the matrix, particular proteins named functional amyloids are now known to reinforce the robustness of the matrix and extracellular DNA (eDNA) can play an important role in the establishment of the biofilm structure [3 - 5]. The stability of the matrix is based on weak physicochemical bonds between the EPS components such as hydrogen bonds, weak electrostatic and ionic interactions, van der Waals interactions and the entanglement of the long biopolymers [6]. The EPS matrix has rheological properties of a gel, giving the ability of biofilms to deform in response to mechanical stress [7].

The matrix can be considered as the "house of the biofilm cells" in which they can organize their life [8]. Indeed,

\footnotetext{
* Address correspondence to this author at the Laboratoire ERRMECe-EA1391, Université de Cergy-Pontoise, 95302 Cergy-Pontoise, France; Tel: +33 134256606; Fax: +33 1 34256694; Email: martino@u-cergy.fr
} 
the matrix is a reservoir of a wide spectrum of extracellular enzymes that act as an external digestion system, which enables microbial cells to degrade molecules and solids. Furthermore, biofim is an area in which all the cells and matrix debris are recycled to allow microbial growth and metabolism. The biofilm mode of life provides several advantages to the microorganisms: resistance to environmental stresses (drying, biocides, nutrient deficiency, flux forces, etc.), increased communication and genetic exchange between microorganisms. Microbial biofilm development can be observed on almost any solid surface in which sufficient moisture is available in nature (mucosal surface, bottom of rivers and lakes, soils, surface of rocks etc.), and in artificial and industrial environments (cooling towers, water filtration membranes, food industry, prostheses and implants, etc.). Several review articles have been previously published about biofilms [9 - 14]. Multispecies biofilm development is a complex and highly regulated developmental process involving different successive steps: adsorption of organic and inorganic molecules and ions to the surface to give a conditioned surface; initial reversible attachment of pioneered microorganisms; irreversible attachment of microorganisms, formation of microcolonies, production of organic matter and EPS, and secondary heterotrophic colonizers recruitment by co-adhesion; development of clonal mosaics within the multispecies biofilm, EPS matrix development and maturation; and active dispersion. The different stages of biofilm formation on stone are shown in Fig. (1).

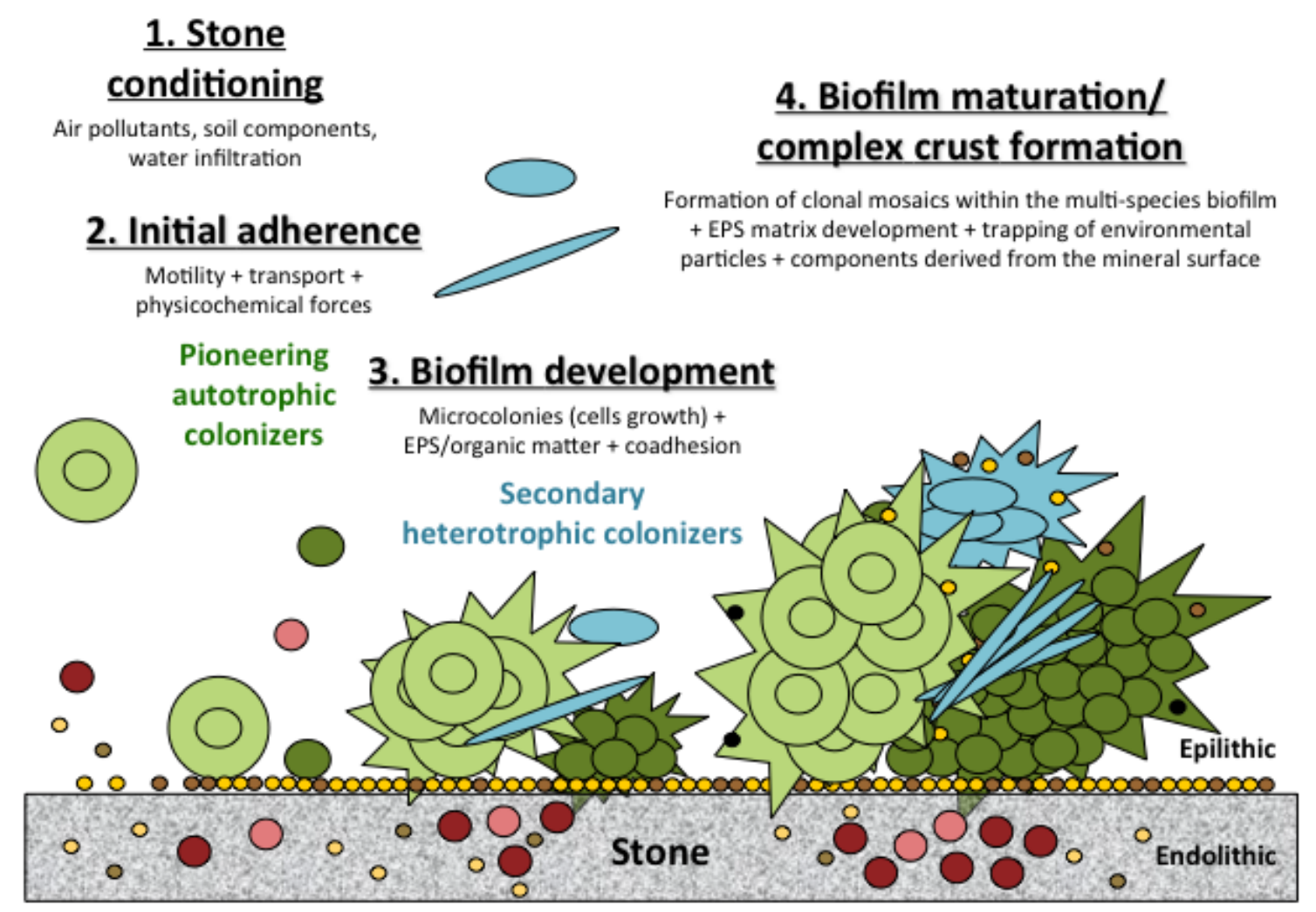

Fig. (1). Different successive steps in the development of multispecies biofilm on stone. Yellow, brown and dark small circles: organic and inorganic molecules and ions. Single and double green circles: pioneering autotrophic colonizers, i.e. cyanobacteria and algae, respectively. Blue cells: secondary heterotrophic colonizers, i.e. bacteria and fungi.

During biofilm development, a complex 3D structure is built in which different cells occupy distinct environments. The physicochemical environment is even heterogeneous within a biofilm due to the existence of several gradients, such as $\mathrm{pH}$-value, redox potential and ionic strength [15]. Depending on its location in the biofilm, each microorganism has to adapt to a particular microenvironment as a more or less high concentration of oxygen, a more or less access to light and / or nutrients. Thus, there is heterogeneity in cellular activity within the biofilm: living but inactive bacteria inhabit some areas. Among the highly diverse biofilms of the human oral microbial biota, different Streptococci species have developed specific properties for colonizing the different oral sites subjected to constantly changing conditions, for competing against competitors and for resisting external aggressions (host immune system, physicochemical shocks, 
and mechanical frictions) [16]. In addition to the heterogeneity in the microbial diversity, there are also differences in constitution of the matrix between different zones of a biofilm (Fig. 2). At the bottom of the biofilm, in close contact to the solid surface, bacterial cells are embedded in a matrix containing high eDNA concentrations, in addition to proteins and polysaccharides that stick the biofilm on the surface. In the core of the biofilm, channels of water carrying ions, nutrients and oxygen cross the biofilm matrix containing high concentrations of EPS, mainly polysaccharides and proteins. In the biofilm detachment area, microbial enzymes digest the EPS matrix and release the cells that can regain expression of flagella and colonize new surfaces through motility.

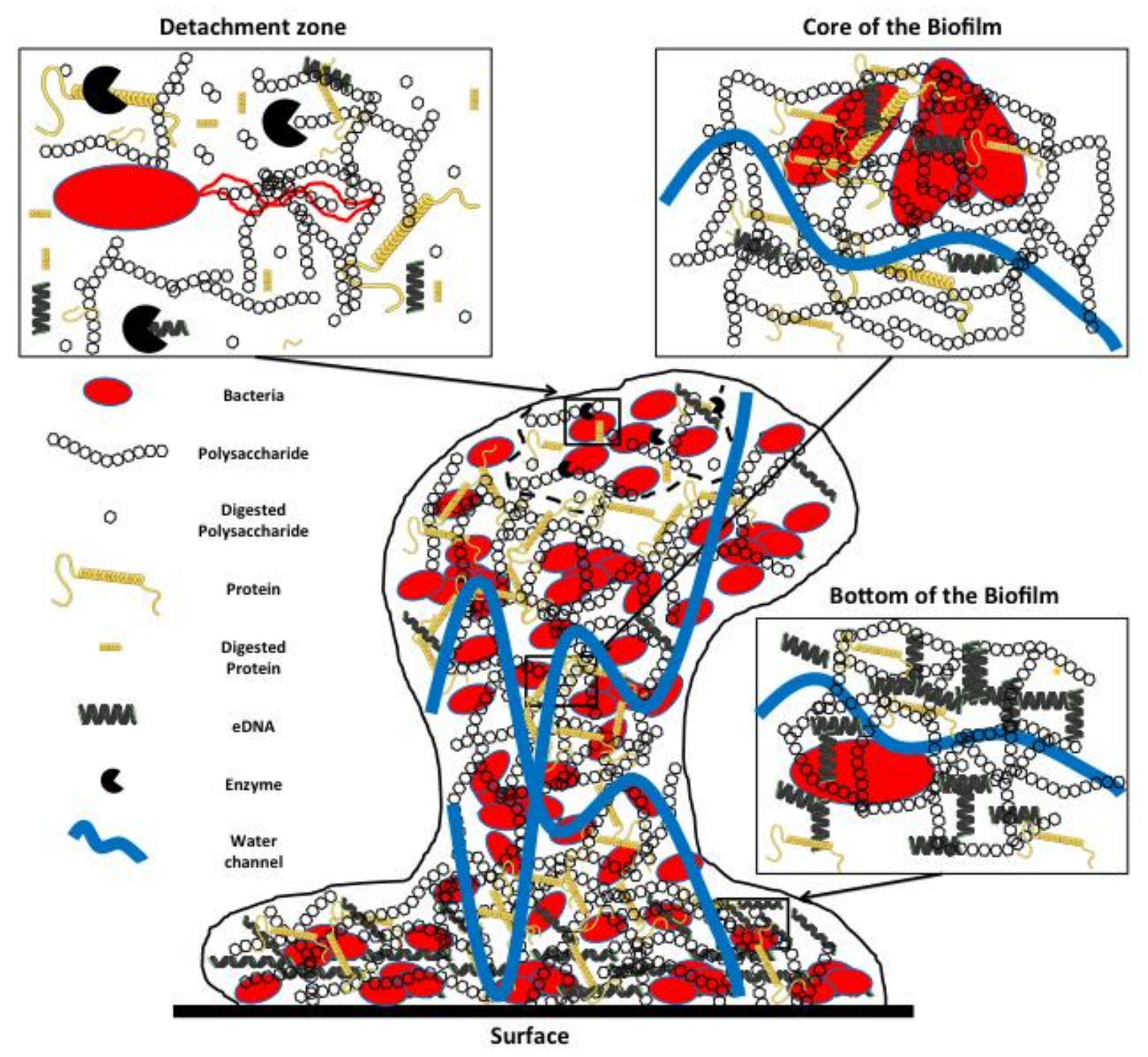

Fig. (2). Heterogeneity between different areas of a mature biofilm.

Biofilm formation can be seen as an evolutionary step between unicellular non specialized organisms and multicellular organisms made of different kinds of specialized cells. The biofilm mode of life needs cell-cell communication systems for the regulation of multicellular behavior. These cell-cell communication systems are based on quorum sensing (QS) signal molecules termed autoinducers (AI) [17]. AI are small diffusible signal molecules produced proportionally to the population density of the producing organism. Beyond a threshold in AI, the cells sense the signal molecule allowing the whole population to initiate a concerted action. This results in phenotypic shift from planktonic to biofilm and in increased resistance to antimicrobial agents inside the biofilm. QS systems based on a variety of AI signal molecules, exist for gram-negative and gram-positive bacteria (Fig. 3). Homoserine lactones, 
quinolones, cyclic dipeptides, fatty acid esters and cyclic thiolactone are examples of AI molecules reflecting signal diversity [17]. Production and detection of most autoinducers are restricted to organisms within species. A particular autoinducer family called autoinducer-2 (AI-2), corresponding to cell-cell communication molecules, all derived from a common precursor (4,5-dihydroxy-2,3-pentanedione), is produced and detected by a wide variety of bacteria [18]. Thus, AI-2 may enable interspecies communication. AI molecules have been detected in biofilms formed on rocks in streams indicating that QS signalling may be involved in stone colonization of artworks and monuments [19]. Other signalling molecules can be involved in multicellular behaviour related to the biofilm mode of life such as ammonia and indole $[20,21]$.

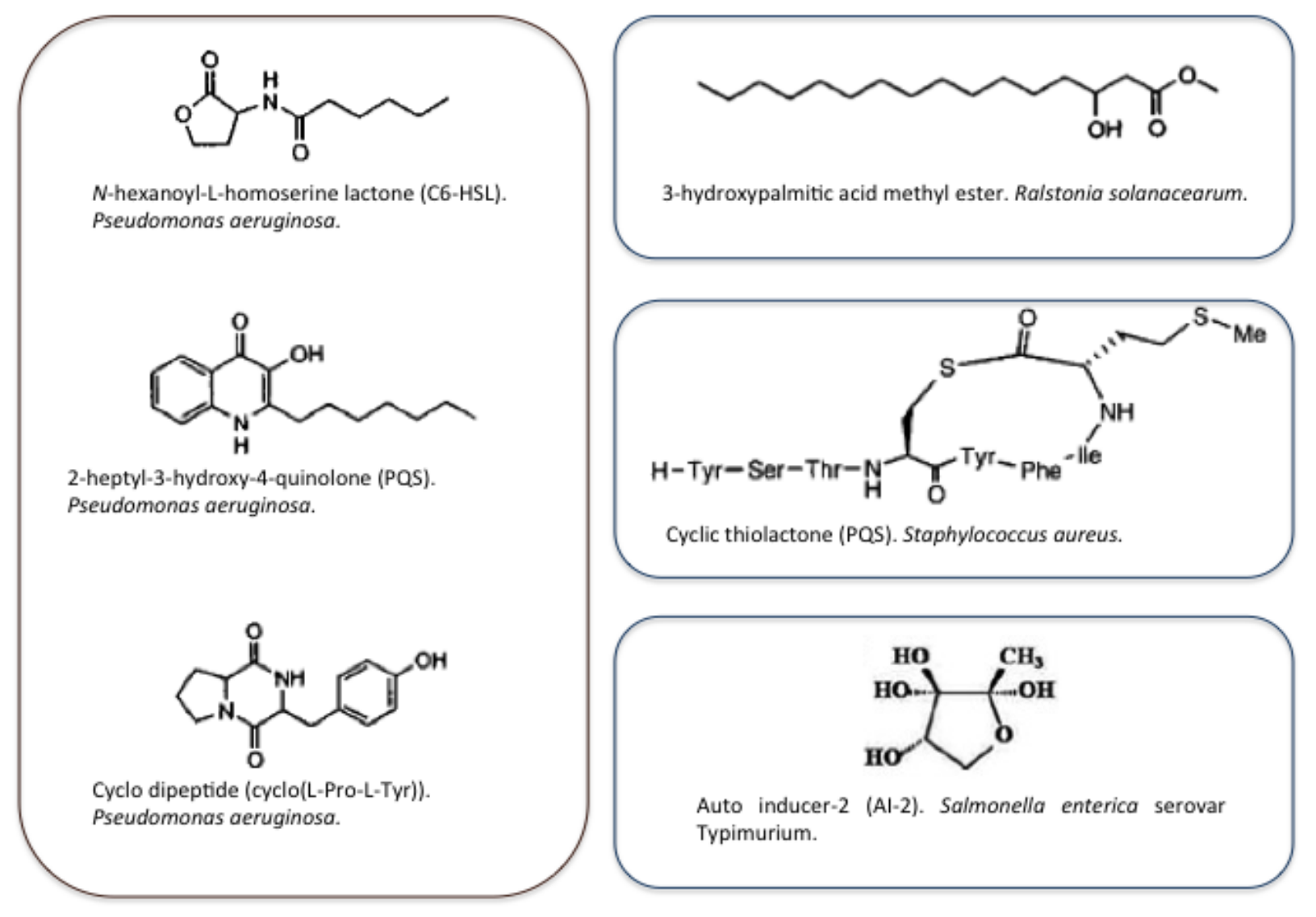

Fig. (3). Examples of Auto Inducer signal molecules produced by gram-negative or gram positive bacteria.

One of the most important features of biofilms is their decreased sensitivity to antimicrobial agents [22]. The decreased sensitivity of sessile microbial cells to antimicrobial agents is lost when bacteria are removed from a biofilm and tested as planktonic cells indicating that it is directly related to the biofilm mode of life [23]. This biofilm tolerance to antimicrobial agents is multifactorial [24]: diffusion limitation of some antibiotics, slow metabolism of certain subpopulations, biofilm specific phenotype, large persister cell populations inside biofilms that neither grow nor die in the presence of microbicidal antibiotics, QS action and activation of the general stress response.

\section{NATURE OF THE MICROORGANISMS COLONIZING STONE MONUMENTS}

The European standard EN15898 defines the main general terms used in the field of conservation of cultural property [25]: an alteration is defined as any change in condition, beneficial or not, intentional or not; deterioration corresponds to gradual change in condition that reduces significance or stability; weathering is an alteration due to exposure to outdoor environment; a treatment is a direct action carried out on an object; cleaning corresponds to removal of unwanted material from an object. The term biodeterioration is not defined in the EN15898 standard but has been defined as "any undesirable change in the properties of a material caused by the vital activities of organism" by Hueck [26]. The microorganisms colonizing the stone monument surface are divers. They can be distinguished according to their location on or in the stone. The microbial colonizers are called epilithic when they are located on top 
of the rock. Microorganisms living inside the rock within cracks and fractures, or in the pore space of sandstone or granites are termed endolithic [27, 28]. Microorganisms colonizing in the depths of the stone can occupy different ecological niches. They are called chasmoendolithic and cryptoendolithic when they live in pre existing fissures and cavities, respectively, and euendolithic when they live in internal zones made by organisms which are themselves capable of actively penetrating the rock substrate [28]. Several types of epilithic and endolithic microorganisms are usually observed on stone monuments [29].

Microorganisms that play a potential role in biodeteriorative processes are autotrophic and heterotrophic bacteria, fungi, algae and lichens [29 - 36]. Phototrophic microorganisms, i.e. microalgae, cyanobacteria and lichens are considered as the pioneering colonizers of the outdoor surface of stone monuments in humid as well as in semi arid and arid environments [37 - 39]. The phototrophic metabolism facilitates the growth of these microorganisms in oligotrophic environments such as stone, forming coloured patinas and incrustations [34]. Moreover, Cyanobacteria can extract and mobilize ions like calcium and potassium from artworks materials for their own nutrition [40]. Lichens are highly resistant to extreme temperature and desiccation, which allow them to easily grow on stone surface. Once installed, cyanobacteria and algae support the growth of heterotrophic organisms such as bacteria and fungi through cells metabolism and cells death [41]: living cyanobacteria and algae synthetize extracellular organic matter and dead cells release cellular constituents that form a nutrient source for heterotrophic microorganisms. Let's take the example of an arid or semi arid environment where filamentous cyanobacteria are the first colonizers by taking advantage of their high resistance to desiccation [39]. The cells spread over the surface, thanks to the mobility of their trichomes, and can even enter the first few millimetres of the material if the porosity of the stone is sufficient. Empty sheaths, released during gliding movements of the trichomes, contribute to increased water retention properties of the stone surface. This makes the surface suitable for colonization of less drought resistant algae. At this stage, the biomass forms surface network of filaments where heterotrophic microorganisms are able to grow by degrading the organic material produced by primary cells conducting a more complex microbial community. The slimy surfaces of this biofilm favour the trapping of environmental particles (pollen, spores, abiotic particles). The mixing of these particles, together with components derived from the mineral surface and cellular debris, into the biofilm layer, gives rise to complex crusts and patinas. Among bacteria, in addition to photoautotrophes, chemolithoautrotrophs (sulfur oxidizing and nitrifying bacteria), chemoorganotrophs (sulfur-reducing bacteria), and chemoheterotrophs (actinomycetes) are common stone monuments colonizers. Actinomycetes species can form close association with cyanobacterial partner inside biofilms formed in Roman catacombs [42, 43]. In these particular biofilms, proteolytic bacteria and gram-negative slime forming bacteria are also present both from biofilm and air samples. Actinobacteria are widely distributed on stone monuments because of their filamentous growth and their ability to use a large range of nitrogen and carbon sources [42]. Chemoheterotrophic bacteria are mainly present in humid environments and form biofilms within the pores of stone materials; in arid and semi arid environments their occurrence is limited. Archaebacteria are less often described from monuments but this may be from the fact that they have been only rarely sought [44 - 47]. Halophilic archae such as Halococcus and Halobacterium have been described in association with areas of the formation of salt efflorescence on the wall surfaces.

Fungi include unicellular ovoid and multicellular filamentous microorganisms. As chemoheterotrophic organisms, fungi are not able to use minerals of the stone or atmospheric $\mathrm{CO}_{2}$ as nutrients but grow on the organic matter produced by other microbial stone colonizers and deposits of organic matter of birds excretes, decayed leaves and aerosols [36]. Stone inhabiting fungi living in moderate or humid climate are different from fungi living in arid and semi-arid environments. In moderate or humid climates, hyphomycetes (Alternaria, Cladosporium, Epicoccum, Aureobasidium and Phoma) that form hyphal networks (mycelia) in the porous space of the stones are mostly present [48]. In arid and semi arid environments, black yeasts and microcolonial fungi are mostly colonizing monuments on and inside the stone often in close association with lichens [49].

Lichens are symbionts of fungi and algae or fungi and cyanobacteria [50]. Lichens are capable of living in extreme temperature and desiccation in environmental conditions more efficiently than fungi, algae or cyanobacteria alone [51]. Like fungi, their growth is favoured by waste material of the birds. Lichens secrete a large range of substances that can be involved in the extraction of nutrients from the mineral surface of stone [52,53].

Quantification and characterization of the sessile biomass colonizing stone are essential prerequisites to ensure the diagnosis of biodeterioration processes and to implement control strategies and appropriate treatments. From the point of view of Sterflinger \& Piñar, it is necessary to complement the taxonomic data of the analysis of microbial communities on art works by studying the physiological activity of the various microbes on and in materials in order to 
get a deeper understanding of biodeterioration processes, to be able to monitor the effect and success of antimicrobial treatments and to develop alternative and non toxic treatment methods, in order to stop or to slow down the biodeteriorative action of the microorganisms [54].

\section{CONSEQUENCES OF COLONIZATION OF STONE MONUMENTS}

\subsection{Bioprotection}

Depending on the situation (climate, type of stone etc.) and on the type of microorganism, the microbial colonization of stone monuments can result in the protection or deterioration of buildings [55 - 57]. Endolithic organic matter associated with lichens colonization can provide waterproofing to the stone and act as a sulfate contamination barrier [58]. Thus, endolithic lichen can induce bioprotection of carboniferous limestone by a passive 'umbrella' or 'thalline shielding' effect [55, 59]: hyphal binding of the rock surface and subsurface appears only to retard, but do not prevent the dissolution of the calcareous substrate [60]. This bioprotection effect depends upon the metabolic activity of the microorganism and thus is subjected to seasonal variations. Lichens colonizing the stone also protect the surface from wind erosion and reduce thermoclastic damaging due to intermittent solar radiation [61]. Seaweeds significantly modify microclimate at the stone surface with a reduction of thermal maxima and damping of short term fluctuations in temperature and relative humidity. Canopy forming macroalgae moderate the surface weathering environment, via a stabilizing effect on microclimate, reducing the efficiency of mechanical breakdown associated with fluctuations of temperature and moisture.

\subsection{Biodeterioration}

Discoloration of the stone surface (greening, blackening, etc.), mainly due to photosynthetic microorganisms (algae, cyanobacteria and lichens), is the most obvious biodeterioration. Cyanobacteria are Gram-negative photosynthetic prokaryotes that occur in both filamentous and coccoid forms. The cyanobacteria on the walls of historic buildings appear to be ecologically remote from aquatic species, forming a particular group [62]. They have a distinct advantage over many other organisms on the outdoor surfaces of monuments in the tropics, thanks to their high resistance to desiccation and to high levels of UV irradiation [63, 64]. Resistance to UV is due to the production of photosynthetic pigments that are also directly responsible for the stone surface discoloration [37]. Algal greening is a common feature in temperate climates [35]. Algal biofilms are capable of reducing the ingress of moisture that likely has a bioprotective action [38]. Nevertheless, previous works have associated the presence of cyanobacteria and algae with physical biodeterioration processes [39]. In addition to discoloration, lichens contribute to deterioration of stone monuments by different mechanisms. They produce carbonic acid by transforming the $\mathrm{CO}_{2}$ produced during respiration and release highly corrosive metabolites such as organic carboxylic acids (like oxalic acid), polyphenolic compounds and chelating compounds that can dissolve the stone $[65,66]$. Lichens attach and penetrate into the pores, cracks and fissures of the stone, leading to mechanical damages [67].

Black fungi are the main agents of biopitting of granite, calcareous limestone and marble [68]. Biopitting is a kind of stone erosion that is the result of chemical (acid attack) and/or mechanical (penetration in the stone) actions of microorganisms, depending on the type of rock. The penetration allows the access of water and nutrients inside the stone, which facilitates the deep colonization of stone by bacteria and thus triggers biochemical attack [31]. In addition to stone pitting, black fungi colonization also induces dark discolorations of stone, in crusting the surface with melanin and imparting a dark, blackish brown appearance to the rock surface [69, 70]. In moderate or humid climates, hyphomycetes are the dominant fungi on rocks while in arid and semiarid climates, black yeasts and microcolonial fungi dominate [71]. Fungi biodeterioration can be difficult to treat because fungi are able to survive chemical treatments [69].

The production of inorganic and organic acids by fungi and bacteria represents a significant part in biodeterioration processes in corrosive aggressiveness of the stone $[72,73]$. Indeed, sulfur oxidizing and nitrifying bacteria are major sulfuric acid and nitric acid producers, respectively $[74,75]$. The sulfur oxidizing bacteria usually live as biofilm communities on mineral surfaces $[76,77]$. Many microorganisms produce carbon dioxide as an end product of their metabolism that contributes to acid attack monuments and to the formation of $\mathrm{CaCO}_{3}$. The inorganic acid attacks also promote the formation of calcium nitrate and gypsum. The crystal growth of salts in the porous structures of stone undergoes damage of the material due to phase changes [78]. By fermentative processes, most bacteria and microscopic fungi produce organic acids that act as complexing agents of metal ions, conducing to stone corrosion through direct and indirect actions. 
Beyond the type of microorganism, the formation of biofilm in itself is a factor of biodeterioration. Indeed, the EPS matrix plays a crucial role in the phenomenon of biodeterioration [79]. EPS can produce mechanical stresses on the stone through the pores of the mineral structure [80] and modify water circulation within the material and its sensitivity to temperature variations [81]. EPS can trap air particulate pollution conducing to a black colour on the surface of monuments in urban environments [30]. Several biofilm and cellular components such as anionic exopolymer, peptides and sugars acids are metal ions chelators that participate in dissolving ions out of the minerals inducing corrosion in them $[79,82,83]$. Other cellular components such as phospholipids, have an emulsifying action that participates in the biodegradation of insoluble compounds such as pyrite [84].

\section{BIOTREATMENTS OF STONE MONUMENTS}

Chemoheterotrophic bacteria such as Bacillus cereus and Myxococcus xanthus can participate in the consolidation of rock and plaster by enhancing calcium carbonate precipitation through passive and active processes [85, 86]. Microbial carbonate precipitation (MCP) can be used to repair calcareous monuments [87] and for crack repair in concrete [88]. MCP is determined by the concentration of dissolved inorganic carbon, the $\mathrm{pH}$, the concentration of calcium ions and the presence of nucleation sites. Most of these factors are provided by the metabolism of the bacteria and the bacterial cell wall acts as a nucleation site [89]. Bacterial EPS mediate $\mathrm{CaCO}_{3}$ morphology and polymorphism [90]. In fact, microbial precipitation results from two different processes: biologically induced precipitation, where precipitation is facilitated by microbial activities; and biologically influenced precipitation, where precipitation is driven by passive interactions of EPS and the geochemical environment [91]. The fact that many EPS are highly hydrated represents an environment where ions and/or molecules can accumulate and reach concentrations higher than the overlying bulk phase [92].

Traditional treatments for black crust removal are based on chemical, mechanical (i.e., abrasive method) and laser treatments and steam cleaning [93 - 96]. Hydrofluoric acid, ammonium carbonate and chelating agents are common chemical reagents used for external stones cleaning [95].

Different bacterial species have been used as biocleaning agents of cultural heritage. Desulfovibrio desulfuricans is efficient to remove the black patina containing large amounts of sulfates from artistic stoneworks, Desulfovibrio vulgaris with an inorganic or organic carrier (sepiolite, gel Hydrobiogel-97 or carbogel) can remove sulfates from marble, and Pseudomonas stutzeri can remove the nitrate pollutants deposited on stones [97 - 101]. Nevertheless, some of these treatments necessitate the immersion of stone surfaces in a liquid medium and the use of living bacteria as biocleaning agents can have deleterious effects due to the chemical reactions between bacterial metabolites and stone substrata provoking destabilization problems [101]. Major improvements of the use of viable bacteria as biocleaning agents for sulfate and nitrate removal have been published recently [102]. Indeed, the use of a combination of Pseudomonas pseudoalcaligenes and D. vulgaris cell cultures entrapped in a multilayer biosystem has been proved to be a fast, non toxic solution, which protects the restorers, the artwork and the environment. Several microorganisms can produce enzymes (amylases, cellulases, glucose oxydases, lipases and proteases) able to remove the patina and clean stone surfaces [103 - 105]. For example, a lipase based cleaning treatment is efficient in the black patina removal [104]. Biocleaning alone is highly time consuming in the presence of thick and compact crusts, thus it can be combined with a chemical treatment such as the use of a non ionic detergent $[96,106]$. There is still a need of research about biocleaning treatments because information about their long term effectiveness and their possible adverse effects is lacking.

Chemical treatments with biocides are currently used to control rock dwelling microorganisms. This common practice can have deleterious ecotoxicity effects and is sometimes inefficient. The application of biocides can provide organic carbon and nitrogen sources of nutrients for microorganisms inhabiting stone monuments since these biocides can be degraded by Pseudomonas sp. strains present on stone [107]. Moreover, fungi are known to resist chemical attack and, therefore, can resist biocides and other anti microbial treatments. Indeed, in the cave of Lascaux, France, successive waves of outbreaks of black fungi were observed after Benzalkonium chloride treatments. The inappropriate use of biocides can also lead to deleterious situations. Indeed, doses below in use concentrations of biocides can stimulate bacterial biofilm formation [108]. Recently, lichen secondary metabolites (LSM) have been successfully evaluated as potential natural biocides against rock dwelling microcolonial fungi, cyanobacteria and green algae [109]. LSM comprise aliphatic, cycloaliphatic, aromatic and terpenic components synthesized by lichen forming fungi [110]. Usnic acid, norstictic acid and parietin were shown to inhibit the growth of different species of microcolonial fungi (Coniosporium perforans, Coniosporium uncinatum, Coniosporium apollinis, and Phaeococcomyces-like sp.) and to induce decreases of intact cells with red chlorophyll epifluorescence onto coccoid cyanobacteria (Chroococcus minutus) 
and green algae (Scenedesmus ecornis). These results suggest that LSM could be used in restoration and conservation programmes against rock dwelling microorganisms. Potential limitations of the use of LSM as biocontrol agents in this context are that some LSM are poorly soluble in water, and are pigmented. Further experiments of the potential impact of LSM on physicochemical properties of stone materials must be carried out to validate their future use in the restoration and conservation of stone materials.
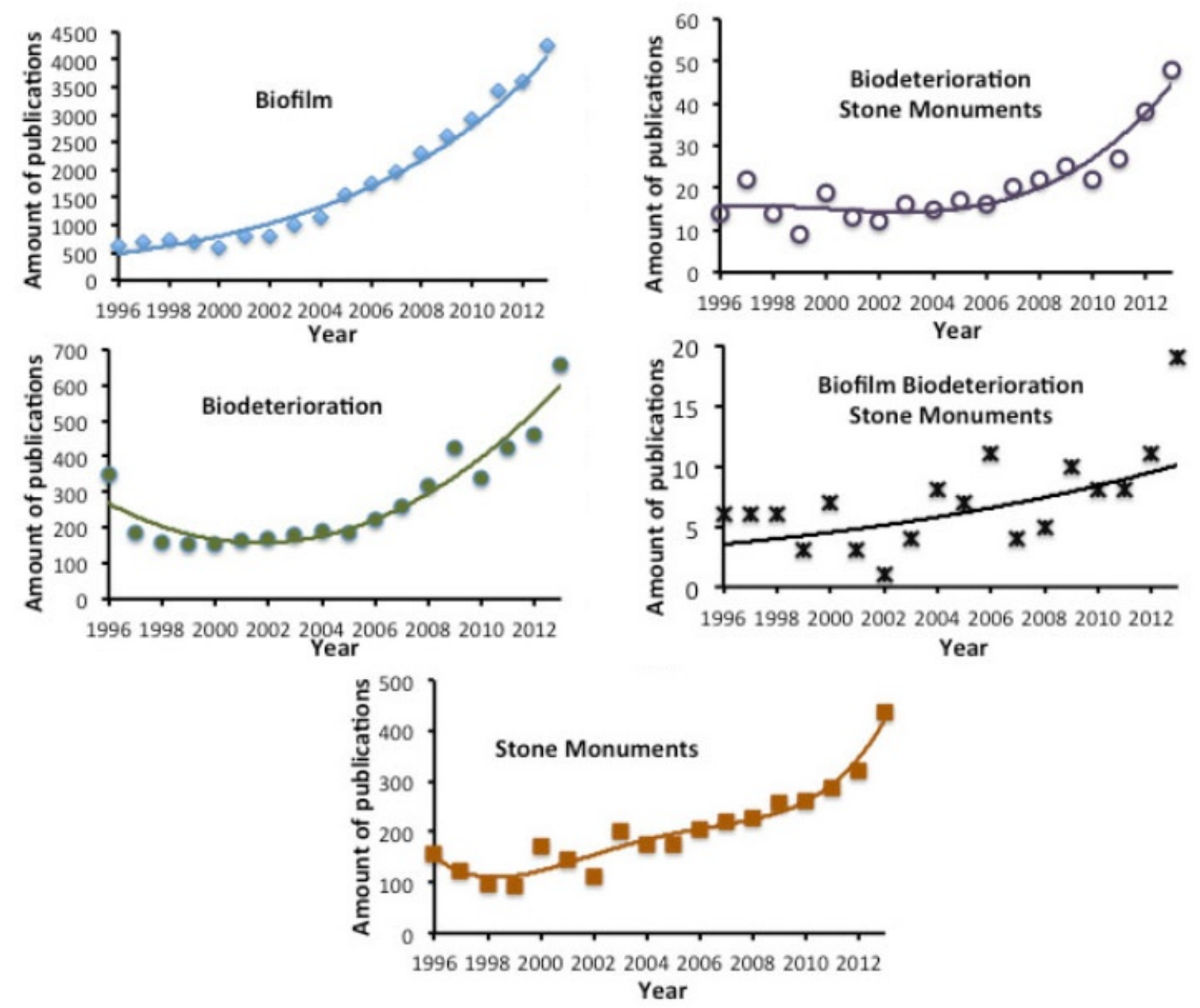

Fig. (4). Evolution of the publications in scientific peer reviewed journals on different topics related to Biofilm formation on stone monuments in the bib-liographic sciencedirect database up to and including 2013.

\section{PUBLICATIONS IN JOURNALS ABOUT BIOFILM ON STONE MONUMENTS}

An analysis of the publications in scientific peer reviewed journals on the topic of Biofilm formation on stone monuments was conducted using the bibliographic science direct database (Fig. 4, Table 1). The research was restricted to articles published up to and including 2013. The keywords used were biofilm; biodeterioration ; stone and monuments ; biodeterioration and stone and monuments ; biofilm and biodeterioration and stone and monuments. The number of articles published on biofilms has increased dramatically since 2001, with the figures risen to over 4000 per year. The number of articles published on biodeterioration was lower but it has constantly been increasing since 2006. The number of articles published on stone monuments and its evolution over time was similar to biodeterioration. When the terms biodeterioration, stone, and monuments were associated, the number of publications found was greatly decreased. This tendency was further accentuated when adding the word biofilm. However, again, changes in the number of publications have been constantly increasing, especially since 2006. As shown in Table 1 presenting the top 5 publication titles and the top five publication topics, "International Biodeterioration and Biodegradation" is the leading journal publishing studies about biodeterioration in general, and biodeterioration of stone monuments in relation with biofilm in particular. Among the top five journals publishing articles about biofilm, only the Journal of Hazardous Materials publishes articles about biodegradation. The other journals correspond to water treatment or biotechnology. 
The major topics corresponding to publications about biodeterioration on stone monuments give a good idea about the research subjects in this domain: black crust, lichen, microbial community, stone monuments, biodeterioration, rock surface and wall paintings. This bibliography is geared towards heritage preservation and many studies are descriptive in field studies. Presently, the published research about biofilms on monuments and stone biodeterioration is relatively marginal in the entire bibliography on biofilms.

\section{CONCLUSION}

There is a lot of research to conduct to develop the knowledge of the specificities of biofilms in the context of stone monument's microbial colonization and biodeterioration. Biofilms on stone monuments represent a fantastic model to study the ecology of biofilms since the microbial biodiversity is very high in this context. Biofilms on stone monuments are made of heterotrophic, autotrophic, procaryotic, eucaryotic, and archaebacteria microorganisms. Part of these microorganisms is entirely dependent on other colonizers to survive and grow while others can use the stone material as a nutrient source. The interactions between these different types of microorganisms, the involvement of quorum sensing in the formation, the behaviour of biofilms on stone monuments and the long term behaviour of biotreated surfaces are still largely unknown.

Table 1. Publications listed in the full-text scientific database ScienceDirect up to and including 2013.

\begin{tabular}{|c|c|c|c|}
\hline Keywords & $\begin{array}{l}\text { Total Publications } \\
\text { in Journals }\end{array}$ & Top Five Publication Titles & Top Five Topics \\
\hline Biofilm & 33,565 & $\begin{array}{l}\text { Water Research }(2,379) \\
\text { Bioressource Technology }(1,930) \\
\text { Water Science \& Technology (729) } \\
\text { Journal of Hazardous Materials (658) } \\
\text { Desalination (614) }\end{array}$ & $\begin{array}{l}\text { Pseudomonas aeruginosa }(690) \\
\text { COD (606) } \\
\text { Staphylococcus aureus }(587) \\
\text { Biofilm formation }(556) \\
\text { COD removal (463) }\end{array}$ \\
\hline Biodeterioration & 6,437 & $\begin{array}{l}\text { International Biodeterioration \& Biodegradation }(2,894) \\
\text { International Biodeterioration (304) } \\
\text { Bioresource Technology (167) } \\
\text { Transactions of the British Mycological Society }(106)\end{array}$ & $\begin{array}{l}\text { USA (113) } \\
\text { International biodeterioration (78) } \\
\text { Service department (69) } \\
\text { Essential oil (55) } \\
\text { Customer service }(51)\end{array}$ \\
\hline Stone Monuments & 5,808 & $\begin{array}{l}\text { The Lancet (405) } \\
\text { Journal of Archaeological Science (342) } \\
\text { Journal of Cultural Heritage (322) } \\
\text { Construction \& Building Materials (189) } \\
\text { Journal of the Franklin Institute (179) }\end{array}$ & $\begin{array}{l}\text { Bronze age (68) } \\
\text { Cultural heritage (58) } \\
\text { Iron age (44) } \\
\text { Medical news (39) } \\
\text { National park (36) }\end{array}$ \\
\hline $\begin{array}{c}\text { Biodeterioration } \\
\text { Stone } \\
\text { Monuments }\end{array}$ & 432 & $\begin{array}{l}\text { International Biodeterioration \& Biodegradation (150) } \\
\text { Science of the Total Environment (57) } \\
\text { Journal of Cultural Heritage (36) } \\
\text { International Biodeterioration (21) } \\
\text { Building \& Environment (18) }\end{array}$ & $\begin{array}{l}\text { Black crust }(10) \\
\text { Lichen }(10) \\
\text { Wall painting }(9) \\
\text { Building material }(8) \\
\text { Cultural heritage }(8)\end{array}$ \\
\hline $\begin{array}{l}\text { Biofilm } \\
\text { Biodeterioration } \\
\text { Stone } \\
\text { Monuments }\end{array}$ & 140 & $\begin{array}{l}\text { International Biodeterioration and Biodegradation (74) } \\
\text { Science of the Total Environment (24) } \\
\text { Building \& Environment (5) } \\
\text { Journal of Cultural Heritage (4) } \\
\text { Journal of Microbial Methods (4) }\end{array}$ & $\begin{array}{l}\text { Microbial community (5) } \\
\text { Stone monuments (5) } \\
\text { Biodeterioration (4) } \\
\text { Rock surface (4) } \\
\text { Wall painting (4) }\end{array}$ \\
\hline
\end{tabular}

In parentheses: number of publications. COD, Chemical Oxygen Demand.

\section{CONFLICT OF INTEREST}

The author confirms that this article content has no conflict of interest.

\section{ACKNOWLEDGEMENTS}

The publication of this paper has been in part made possible by a grant from the Labex Patrima.

\section{REFERENCES}

[1] Schmidt, J.; Flemming, H.C. Water binding in biofilms. Water Sci. Technol., 1999, 39, 77-82. [http://dx.doi.org/10.1016/S0273-1223(99)00153-5]

[2] Sutherland, I. Biofilm exopolysaccharides: a strong and sticky framework. Microbiology, 2001, 147(Pt 1), 3-9. a [http://dx.doi.org/10.1099/00221287-147-1-3] [PMID: 11160795]

[3] Lembre, P.; Lorentz, C.; Di Martino, P. Exopolysaccharides of the biofilm matrix: a complex biophysical world. In: The Complex World of Polysaccharides, Desiree Nedra Karunaratne; InTech, 2012. 
[http://dx.doi.org/10.5772/51213]

[4] Lembré, P.; Di Martino, P.; Vendrely, C. Amyloid peptides derived from CsgA and FapC modify the viscoelastic properties of biofilm model matrices. Biofouling, 2014, 30(4), 415-426.

[http://dx.doi.org/10.1080/08927014.2014.880112] [PMID: 24592895]

[5] Whitchurch, C.B.; Tolker-Nielsen, T.; Ragas, P.C.; Mattick, J.S. Extracellular DNA required for bacterial biofilm formation. Science, 2002, 295(5559), 1487.

[http://dx.doi.org/10.1126/science.295.5559.1487] [PMID: 11859186]

[6] Mayer, C.; Moritz, R.; Kirschner, C.; Borchard, W.; Maibaum, R.; Wingender, J.; Flemming, H.C. The role of intermolecular interactions: studies on model systems for bacterial biofilms. Int. J. Biol. Macromol., 1999, 26(1), 3-16. [http://dx.doi.org/10.1016/S0141-8130(99)00057-4] [PMID: 10520951]

[7] Houari, A.; Picard, J.; Habarou, H.; Galas, L.; Vaudry, H.; Heim, V.; Di Martino, P. Rheology of biofilms formed at the surface of NF membranes in a drinking water production unit. Biofouling, 2008, 24(4), 235-240.

[http://dx.doi.org/10.1080/08927010802023764] [PMID: 18392991]

[8] Flemming, H.C. The perfect slime. Colloids Surf. B Biointerfaces, 2011, 86(2), 251-259.

[http://dx.doi.org/10.1016/j.colsurfb.2011.04.025] [PMID: 21592744]

[9] Garrett, T.R.; Bhakoo, M.; Zhang, Z. Bacterial adhesion and biofilms on surfaces. Prog. Nat. Sci., 2008, 18(9), $1049-1056$. [http://dx.doi.org/10.1016/j.pnsc.2008.04.001]

[10] Jefferson, K.K. What drives bacteria to produce a biofilm? FEMS Microbiol. Lett., 2004, 236(2), 163-173. [http://dx.doi.org/10.1111/j.1574-6968.2004.tb09643.x] [PMID: 15251193]

[11] Molin, S.; Tolker-Nielsen, T. Gene transfer occurs with enhanced efficiency in biofilms and induces enhanced stabilisation of the biofilm structure. Curr. Opin. Biotechnol., 2003, 14(3), 255-261.

[http://dx.doi.org/10.1016/S0958-1669(03)00036-3] [PMID: 12849777]

[12] Monroe, D. Looking for chinks in the armor of bacterial biofilms. PLoS Biol., 2007, 5(11), e307. [http://dx.doi.org/10.1371/journal.pbio.0050307] [PMID: 18001153]

[13] O’Toole, G.; Kaplan, H.B.; Kolter, R. Biofilm formation as microbial development. Annu. Rev. Microbiol., 2000, 54, 49-79. [http://dx.doi.org/10.1146/annurev.micro.54.1.49] [PMID: 11018124]

[14] Sauer, K. The genomics and proteomics of biofilm formation. Genome Biol., 2003, 4(6), 219. [http://dx.doi.org/10.1186/gb-2003-4-6-219] [PMID: 12801407]

[15] Stewart, P.S.; Franklin, M.J. Physiological heterogeneity in biofilms. Nat. Rev. Microbiol., 2008, 6(3), 199-210. [http://dx.doi.org/10.1038/nrmicro1838] [PMID: 18264116]

[16] Nicolas, G.G.; Lavoie, M.C. Streptococcus mutans and oral streptococci in dental plaque. Can. J. Microbiol., 2011, 57(1), 1-20. [http://dx.doi.org/10.1139/W10-095] [PMID: 21217792]

[17] Garg, N; Manchanda, G; Kumar, A. Bacterial quorum sensing: circuits and applications. Antonie Van Leeuwenhoek, 2014, 105(2), 289-305. [http://dx.doi.org/10.1007/s10482-013-0082-3]

[18] Pereira, C.S.; Thompson, J.A.; Xavier, K.B. AI-2-mediated signalling in bacteria. FEMS Microbiol. Rev., 2013, 37(2), 156-181. [http://dx.doi.org/10.1111/j.1574-6976.2012.00345.x] [PMID: 22712853]

[19] McLean, R.J.; Whiteley, M.; Stickler, D.J.; Fuqua, W.C. Evidence of autoinducer activity in naturally occurring biofilms. FEMS Microbiol. Lett., 1997, 154(2), 259-263.

[http://dx.doi.org/10.1111/j.1574-6968.1997.tb12653.x] [PMID: 9311122]

[20] Bernier, S.P.; Létoffé, S.; Delepierre, M.; Ghigo, J.M. Biogenic ammonia modifies antibiotic resistance at a distance in physically separated bacteria. Mol. Microbiol., 2011, 81(3), 705-716. [http://dx.doi.org/10.1111/j.1365-2958.2011.07724.x] [PMID: 21651627]

[21] Martino, P.D.; Fursy, R.; Bret, L.; Sundararaju, B.; Phillips, R.S. Indole can act as an extracellular signal to regulate biofilm formation of Escherichia coli and other indole-producing bacteria. Can. J. Microbiol., 2003, 49(7), 443-449. [http://dx.doi.org/10.1139/w03-056] [PMID: 14569285]

[22] Stewart, P.S.; Costerton, J.W. Antibiotic resistance of bacteria in biofilms. Lancet, 2001, 358(9276), $135-138$. [http://dx.doi.org/10.1016/S0140-6736(01)05321-1] [PMID: 11463434]

[23] Hentzer, M.; Eberl, L.; Nielsen, J.; Givskov, M. Quorum sensing : a novel target for the treatment of biofilm infections. BioDrugs, 2003, $17(4), 241-250$.

[http://dx.doi.org/10.2165/00063030-200317040-00003] [PMID: 12899641]

[24] Drenkard, E. Antimicrobial resistance of Pseudomonas aeruginosa biofilms. Microbes Infect., 2003, 5(13), $1213-1219$. [http://dx.doi.org/10.1016/j.micinf.2003.08.009] [PMID: 14623017]

[25] Conservation of cultural property - Main general terms and definitions $E N 15898,2011$.

[26] Hueck, H.J. The biodeterioration of materials-an appraisal. Int. Biodeterior. Biodegradation, 2001, 48, 5-11. [http://dx.doi.org/10.1016/S0964-8305(01)00061-0] 
[27] Golubic, S.; Perkins, R.D.; Lukas, K.J. Boring microorganisms and microborings in carbonate substrates. In: The Study of Trace Fossils; Frey, R.W., Ed.; Springer Verlage: New York, 1975; pp. 229-259. [http://dx.doi.org/10.1007/978-3-642-65923-2_12]

[28] Golubic, S.; Friedmann, E.I.; Schneider, J. The lithobiontic ecological niche, with special reference to microorganisms. J. Sediment. Petrol., 1981, 51, 475-478.

[29] de los Rios, A.; Galván, V.; Ascaso, C. In situ microscopical diagnosis of biodeterioration processes at the convent of Santa Cruz la Real, Segovia, Spain. Int. Biodeterior. Biodegradation, 2004, 54, 113-120. [http://dx.doi.org/10.1016/j.ibiod.2004.03.020]

[30] Gómez-Alarcón, G.; Cirellos, B.; Flores, M.; Lorenzo, J. Microbial communities and alteration processes in monuments at Alcala de Henares. Spain. Sci. Total Environ., 1995, 167, 231-239. [http://dx.doi.org/10.1016/0048-9697(95)04584-N]

[31] Gómez-Alarcón, G.; de la Torre, M.A. The effect of filamentous fungi on stone monuments: the Spanish experience. In: Building Mycology. Management of Decay and Health in Buildings; Singh, J., Ed.; Chapman and Hall: UK, 1994; pp. $295-309$.

[32] Tomaselli, L.; Lamenti, G.; Bosco, M.; Tiano, P. Biodiversity of photosynthetic microorganisms dwelling on stone monuments. Int. Biodeterior. Biodegradation, 2000, 46, 251-258.

[http://dx.doi.org/10.1016/S0964-8305(00)00078-0]

[33] Urzi, C. Microbial deterioration of rocks and marble monuments in Mediterranean Basin: A review. Corros Rev., 2004, 22 , $441-457$. [http://dx.doi.org/10.1515/CORRREV.2004.22.5-6.441]

[34] Gaylarde, C.C.; Gaylarde, P.M. A comparative study of the major microbial biomass of biofilms on exteriors of buildings in Europe and Latin America. Int. Biodeterior. Biodegradation, 2005, 55, 131-139. [http://dx.doi.org/10.1016/j.ibiod.2004.10.001]

[35] Cutler, N.; Viles, H. Eukaryotic microorganisms and stone biodeterioration. Geomicrobiol. J., 2010, 27(6-7), 630-646. [http://dx.doi.org/10.1080/01490451003702933]

[36] Sterflinger, K. Fungi: their role in deterioration of cultural heritage. Fungal Biol. Rev., 2010, 24, 47-55. [http://dx.doi.org/10.1016/j.fbr.2010.03.003]

[37] Crispim, C.A.; Gaylarde, P.M.; Gaylarde, C.C. Algal and cyanobacterial biofilms on calcareous historic buildings. Curr. Microbiol., 2003, 46(2), 79-82. [http://dx.doi.org/10.1007/s00284-002-3815-5] [PMID: 12520359]

[38] Cutler, N.A.; Viles, H.A.; Ahmad, S.; McCabe, S.; Smith, B.J. Algal 'greening' and the conservation of stone heritage structures. Sci. Total Environ., 2013, 442, 152-164. [http://dx.doi.org/10.1016/j.scitotenv.2012.10.050] [PMID: 23178775]

[39] Ortega-Calvo, J.J.; Hernandez-Marine, M.; Saiz-Jimenez, C. Biodeterioration of building materials by cyanobacteria and algae. Int. Biodeterior., 1991, 28, 165-185. [http://dx.doi.org/10.1016/0265-3036(91)90041-O]

[40] Albertano, P.; Moscone, D.; Palleschi, G. Cyanobacteria attack rocks (CATS): control and preventive strategies to avoid damage caused by cyanobacteria and associated microorganisms in Roman hypogean monuments. In: Balkema: Molecular Biology and Cultural Heritage; SaizJimenez, C., Ed.; Lisse, 2003; pp. 151-162.

[41] De la Torre, M.A.; Gomez-Alarcon, G.; Melgarejo, P.; Saiz-Jimenez, C. Fungi in weathered sandstone from Salamanca Cathedral. Spain. Sci. Total Environ., 1991, 107, 159-168. [http://dx.doi.org/10.1016/0048-9697(91)90257-F]

[42] Saarela, M.; Alakomi, H.L.; Suihko, M.L.; Maunuksela, L.; Raaska, L.; Mattila-Sandholm, T. Heterotrophic microorganisms in air and biofilm samples from Roman catacombs, with special emphasis on actinobacteria and fungi. Int. Biodeterior. Biodegradation, 2004, 54, 27-37. [http://dx.doi.org/10.1016/j.ibiod.2003.12.003]

[43] Sanchez-Moral, S.; Luque, L.; Cuezva, S.; Soler, V.; Benavente, D.; Laiz, L.; Gonzalez, J.M.; Saiz-Jimenez, C. Deterioration of building materials in Roman catacombs: the influence of visitors. Sci. Total Environ., 2005, 349(1-3), 260-276. [http://dx.doi.org/10.1016/j.scitotenv.2004.12.080] [PMID: 16198686]

[44] Ettenauer, J.; Sterflinger, K.; Piñar, G. Cultivation and molecular monitoring of halophilic microorganisms inhabiting an extreme environment presented by a salt-attacked monument. Int. J. Astrobiol., 2010, 9, 59-72. [http://dx.doi.org/10.1017/S1473550409990383]

[45] Laiz, L.; Romanowska-Deskins, A.; Saiz-Jimenez, C. Survival of a bacterial/archael consortium on building materials as revealed by molecular methods. Int. Biodeterior. Biodegradation, 2011, 65(7), 1100-1103. [http://dx.doi.org/10.1016/j.ibiod.2011.04.010]

[46] Piñar, G.; Saiz-Jimenez, C.; Schabereiter-Gurtner, C.; Blanco-Varela, M.T.; Lubitz, W.; Rölleke, S. Archaeal communities in two disparate deteriorated ancient wall paintings: detection, identification and temporal monitoring by denaturing gradient gel electrophoresis. FEMS Microbiol. Ecol., 2001, 37, 45-54. [http://dx.doi.org/10.1016/S0168-6496(01)00144-1] 
[47] Piñar, G.; Ripka, K.; Weber, J.; Sterflinger, K. The micro biota of a sub-surface monument the medieval chapel of St. Virgil (Vienna, Austria). Int. Biod. Degrad., 2009, 63, 851-859. [http://dx.doi.org/10.1016/j.ibiod.2009.02.004]

[48] Sterflinger, K. Fungi as geologic agents. Geomicrobiol. J., 2000, 17, 97-124. [http://dx.doi.org/10.1080/01490450050023791]

[49] Sterflinger, K. Black yeasts and meristematic fungi: ecology, diversity and identification. In: Yeast Handbook: Biodiversity and Ecophysiology of Yeasts; Rosa, C.; Gabor, P., Eds.; Springer: New York, 2005; Vol. 1, pp. 505-518.

[50] Oksanen, I. Ecological and biotechnological aspects of lichens. Appl. Microbiol. Biotechnol., 2006, 73(4), $723-734$. [http://dx.doi.org/10.1007/s00253-006-0611-3] [PMID: 17082931]

[51] Smith, D.C.; Douglas, A.E. The biology of symbiosis; Arnold: London, 1987.

[52] Bjelland, T.; Thorseth, I.H. Comparative studies of the lichen-rock interface of four lichens in Vingen, western Norway. Chem. Geol., 2002, 192, 81-98. [http://dx.doi.org/10.1016/S0009-2541(02)00193-6]

[53] Huneck, S.; Yoshimura, I. Identification of Lichen Substance; Springer-Verlag: Berlin, 1996. [http://dx.doi.org/10.1007/978-3-642-85243-5]

[54] Sterflinger, K.; Piñar, G. Microbial deterioration of cultural heritage and works of art tilting at windmills? Appl. Microbiol. Biotechnol., 2013, 97(22), 9637-9646. [http://dx.doi.org/10.1007/s00253-013-5283-1] [PMID: 24100684]

[55] Ariño, X.; Ortega-Calvo, J.J.; Gomez-Bolea, A.; Saiz-Jimenez, C. Lichen colonisation of the Roman pavement at Baelo Claudia (Cadiz, Spain): biodeterioration vs. bioprotection. Sci. Total Environ., 1995, 167, 353-363. [http://dx.doi.org/10.1016/0048-9697(95)04595-R]

[56] Coombes, M.A.; Naylor, L.A.; Viles, H.A.; Thompson, R.C. Bioprotection and disturbance: Seaweed, microclimatic stability and conditions for mechanical weathering in the intertidal zone. Geomorphology, 2013, 202, 4-14. [http://dx.doi.org/10.1016/j.geomorph.2012.09.014]

[57] Sternberg, T.; Viles, H.; Cathersides, A. Evaluating the role of ivy (Hedera helix) in moderating wall surface microclimates and contributing to the bioprotection of historic buildings. Build. Environ., 2011, 46, 293-297. [http://dx.doi.org/10.1016/j.buildenv.2010.07.017]

[58] Concha-Lozano, N.; Gaudona, P.; Pages, J.; de Billerbeck, G.; Lafon, D.; Eterradossi, O. Protective effect of endolithic fungal hyphae on oolitic limestone buildings. J. Cult. Herit., 2012, 13, 120-127.

[http://dx.doi.org/10.1016/j.culher.2011.07.006]

[59] Mottershead, D.; Lucas, G. The role of lichens in inhibiting erosion of a soluble rock. Lichenologist, 2000, 32(6), 601-609. [http://dx.doi.org/10.1006/lich.2000.0300]

[60] de la Rosa, J.P.; Warke, P.A.; Smith, B.J. The effects of lichen cover upon the rate of solutional weathering of limestone. Geomorphology, 2014, 220, 81-92. [http://dx.doi.org/10.1016/j.geomorph.2014.05.030]

[61] Carter, N.E.; Viles, H.A. Lichen hotspots: raised rock temperatures beneath Verrucaria nigrescens on limestone. Geomorphology, 2004, $62(1-2), 1-16$. [http://dx.doi.org/10.1016/j.geomorph.2004.02.001]

[62] Crispim, C.A.; Gaylarde, P.M.; Gaylarde, C.C.; Neilan, B.A. Deteriogenic cyanobacteria on historic buildings in Brazil detected by culture and molecular techniques. Int. Biodeterior. Biodegradation, 2006, 57, 239-243. [http://dx.doi.org/10.1016/j.ibiod.2006.03.001]

[63] Chazal, N.M.; Smith, G.D. Characterization of a brown Nostoc species from Java that is resistant to high light intensity and UV. Microbiology, 1994, 140, 3183-3189. [http://dx.doi.org/10.1099/13500872-140-11-3183]

[64] Potts, M. Desiccation tolerance of prokaryotes. Microbiol. Rev., 1994, 58(4), 755-805. [PMID: 7854254]

[65] Adamo, P.; Violante, P. Weathering of rocks and neogenesis of minerals associated with lichen activity. Appl. Clay Sci., 2000, 16, 229-256. [http://dx.doi.org/10.1016/S0169-1317(99)00056-3]

[66] Kiurski, J.S.; Ranogajec, J.G.; Ujhelji, A.L.; Radeka, M.M.; Bokorov, M.T. Evaluation of the effect of lichens on ceramic roofing tiles by scanning electron microscopy and energy dispersive spectroscopy analyses. Scanning, 2005, 27(3), 113-119. [http://dx.doi.org/10.1002/sca.4950270302] [PMID: 15934501]

[67] Favero-Longo, S.E.; Castelli, D.; Salvadori, O.; Belluso, E.; Piervittori, R. Pedogenetic action of the lichens Lecidea atrobrunnea, Rhizocarpon geographicum gr. and Sporastatia testudinea on serpentinized ultramafic rocks in an alpine environment. Int. Biodeterior. Biodegradation, 2005, 56, 17-27. [http://dx.doi.org/10.1016/j.ibiod.2004.11.006]

[68] Sterflinger, K.; Krumbein, W.E. Dematiaceous fungi as a major agent of biopitting on Mediterranean marbles and limestones. Geomicrobiol. 
J., 1997, 14, 219-230.

[http://dx.doi.org/10.1080/01490459709378045]

[69] Marvasi, M.; Donnarumma, F.; Frandi, A. Black microcolonial fungi as deteriogens of two famous marble statues in Florence, Italy. Int. Biodeterior. Biodegradation, 2012, 68, 36-44. [http://dx.doi.org/10.1016/j.ibiod.2011.10.011]

[70] Sert, H.B.; Sümbül, H.; Sterflinger, K. Microcolonial fungi from antique marbles in Perge/Side/Termessos (Antalya/Turkey). Antonie van Leeuwenhoek, 2007, 91(3), 217-227. [http://dx.doi.org/10.1007/s10482-006-9111-9] [PMID: 17080290]

[71] Rosling, A.; Finlay, R.D.; Gadd, G.M. Geomycology. Fungal Biol. Rev., 2009, 23, 91-93. [http://dx.doi.org/10.1016/j.fbr.2010.03.005]

[72] Herrera, L.K.; Videla, H.A. The importance of atmospheric effects on biodeterioration of cultural heritage constructional materials. Int. Biodeterior. Biodegradation, 2004, 54, 125-134. [http://dx.doi.org/10.1016/j.ibiod.2004.06.002]

[73] Li, X.S.; Sato, T.; Ooiwa, Y.; Kusumi, A.; Gu, J.D.; Katayama, Y. Oxidation of elemental sulfur by Fusarium solani strain THIF01 harboring endobacterium Bradyrhizobium sp. Microb. Ecol., 2010, 60(1), 96-104. [http://dx.doi.org/10.1007/s00248-010-9699-1] [PMID: 20571793]

[74] Sand, W.; Bock, E. Biodeterioration of ceramic materials by biogenic acids. Int. Biodeterior., 1991, $27(2), 175-183$. [http://dx.doi.org/10.1016/0265-3036(91)90009-G]

[75] Sand, W. Microbial mechanisms of deterioration of inorganic substrates-A general mechanistic overview. Int. Biodeterior. Biodegradation, 1997, 40(2-4), 183-190. [http://dx.doi.org/10.1016/S0964-8305(97)00048-6]

[76] Beech, I.B.; Sunner, J. Biocorrosion: towards understanding interactions between biofilms and metals. Curr. Opin. Biotechnol., 2004, 15(3), $181-186$. [http://dx.doi.org/10.1016/j.copbio.2004.05.001] [PMID: 15193324]

[77] Jerez, C.A. The use of genomics, proteomics and other OMICS technologies for the global understanding of biomining microorganisms. Hydrometallurgy, 2008, 94(1-4), 162-169. [http://dx.doi.org/10.1016/j.hydromet.2008.05.032]

[78] Steiger, M. Crystal growth in porous materials-I: The crystallization pressure of large crystals. J. Cryst. Growth, 2005, 282(3-4), 455-469. [http://dx.doi.org/10.1016/j.jcrysgro.2005.05.007]

[79] Sand, W.; Gehrke, T. Extracellular polymeric substances mediate bioleaching/biocorrosion via interfacial processes involving iron(III) ions and acidophilic bacteria. Res. Microbiol., 2006, 157(1), 49-56. [http://dx.doi.org/10.1016/j.resmic.2005.07.012] [PMID: 16431087]

[80] Guiamet, P.; Crespo, M.; Lavin, P.; Ponce, B.; Gaylarde, C.; de Saravia, S.G. Biodeterioration of funeral sculptures in La Recoleta Cemetery, Buenos Aires, Argentina: pre and post-intervention studies. Colloids Surf. B Biointerfaces, 2013, 101, 337-342. [http://dx.doi.org/10.1016/j.colsurfb.2012.06.025] [PMID: 23010038]

[81] Warscheid, T.; Becker, T.W.; Resende, M.A. Biodeterioration of stone: a comparison between (sub)tropical and moderate climate zones. Int. Biodeterior. Biodegradation, 1996, 37(1-2), 124. [http://dx.doi.org/10.1016/0964-8305(96)84351-4]

[82] Kaplan, D.; Christiaen, D.; Arad, S.M. Chelating properties of extracellular polysaccharides from Chlorella spp. Appl. Environ. Microbiol., 1987, 53(12), 2953-2956 [PMID: 16347510]

[83] Kinzler, K.; Gehrke, T.; Telegdi, J.; Sand, W. Bioleaching-a result of interfacial processes caused by extracellular polymeric substances (EPS). Hydrometallurgy, 2003, 71(1-2), 83-88. [http://dx.doi.org/10.1016/S0304-386X(03)00176-2]

[84] Shively, J.M.; Benson, A.A. Phospholipids of Thiobacillus thiooxidans. J. Bacteriol., 1967, 94(5), 1679-1683. [PMID: 6066049]

[85] Ettenauer, J.; Piñar, G.; Sterflinger, K.; Gonzalez-Muñoz, M.T.; Jroundi, F. Molecular monitoring of the microbial dynamics occurring on historical limestone buildings during and after the in situ application of different bio consolidation treatments. Sci. Total Environ., 2011, 409(24), 5337-5352. [http://dx.doi.org/10.1016/j.scitotenv.2011.08.063] [PMID: 21944202]

[86] Tiano, P.; Biagiotti, L.; Mastromei, G. Bacterial bio mediated calcite precipitation for monumental stones conservation: methods of evaluation. J. Microbiol. Methods, 1999, 36(1-2), 139-145. [http://dx.doi.org/10.1016/S0167-7012(99)00019-6] [PMID: 10353808]

[87] Jimenez-Lopez, C.; Jroundi, F.; Pascolini, C. Consolidation of quarry calcarenite by calcium carbonate precipitation induced by bacteria activated among the microbiota inhabiting the stone. Int. Biodeterior. Biodegradation, 2008, 62, 352-363. [http://dx.doi.org/10.1016/j.ibiod.2008.03.002]

[88] Dejong, J.T.; Fritzges, M.B.; Nusslein, K. Microbially induced cementation to control sand response to undrained shear. J. Geotech. 
Geoenviron. Eng., 2006, 132, 1381-1392.

[http://dx.doi.org/10.1061/(ASCE)1090-0241(2006)132:11(1381)]

[89] Hammes, F.; Verstraete, W. Key roles of pH and calcium metabolism in microbial carbonate precipitation. Rev. Environ. Sci. Biotechnol., 2002, l(1), 3-7. [http://dx.doi.org/10.1023/A:1015135629155]

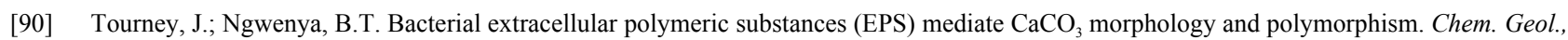
2009, 262, 138-146. [http://dx.doi.org/10.1016/j.chemgeo.2009.01.006]

[91] Decho, A.W. Overview of biopolymer-induced mineralization: What goes on in biofilms? Ecol. Eng., 2010, 36, $137-144$. [http://dx.doi.org/10.1016/j.ecoleng.2009.01.003]

[92] Sutherland, I.W. The biofilm matrix-an immobilized but dynamic microbial environment. Trends Microbiol., 2001, 9(5), 222-227. b [http://dx.doi.org/10.1016/S0966-842X(01)02012-1] [PMID: 11336839]

[93] Slaton, D.; Normandin, K.C. Masonry cleaning technologies. J. Archit. Conserv., 2005, 11, 7-31. [http://dx.doi.org/10.1080/13556207.2005.10784950]

[94] Nugari, M.P.; Salvadori, O. Molecular Biology and Cultural Heritage; Jimenez, Saiz-, Ed.; Lisse, Swets \& Zeitlinger, 2003.

[95] Gaspar, P.; Hubbard, C.; McPhail, D.; Cummings, A. A topographical assessment and comparison of conservation cleaning treatments. J. Cult. Herit., 2003, 4, 294s-302s.

[http://dx.doi.org/10.1016/S1296-2074(02)01211-6]

[96] Gioventù, E.; Lorenzi, P.F.; Villa, F. Comparing the bioremoval of black crusts on colored artistic lithotypes of the Cathedral of Florence with chemical and laser treatment. Int. Biodeterior. Biodegradation, 2011, 65, 832-839. [http://dx.doi.org/10.1016/j.ibiod.2011.06.002]

[97] Cappitelli, F.; Zanardini, E.; Ranalli, G.; Mello, E.; Daffonchio, D.; Sorlini, C. Improved methodology for bioremoval of black crusts on historical stone artworks by use of sulfate-reducing bacteria. Appl. Environ. Microbiol., 2006, 72(5), 3733-3737. [http://dx.doi.org/10.1128/AEM.72.5.3733-3737.2006] [PMID: 16672524]

[98] Cappitelli, F.; Toniolo, L.; Sansonetti, A.; Gulotta, D.; Ranalli, G.; Zanardini, E.; Sorlini, C. Advantages of using microbial technology over traditional chemical technology in removal of black crusts from stone surfaces of historical monuments. Appl. Environ. Microbiol., 2007, 73(17), 5671-5675. [http://dx.doi.org/10.1128/AEM.00394-07] [PMID: 17601804]

[99] Ranalli, G. Rapid Diagnosis of Microbial Growth and Biocide Treatments on Stone Materials by Bioluminescent Low Light Imaging Technique. In: Proceedings of the $9^{\text {th }}$ International Congress on Deterioration and Conservation of Stone; Fassina, V., Ed.; Elsevier: Venice, 2000; pp. 499-505. [http://dx.doi.org/10.1016/B978-044450517-0/50134-3]

[100] Ranalli, G.; Chiavarini, M.; Guidetti, V. The Use of Microorganism for the Removal of Nitrates and Organic Substance on Artistic Stoneworks. In: Proceedings of the $8^{\text {th }}$ International Congress on Deterioration \& Conservation of the Stone; Riederer, J, Ed.; , 1996; pp. Berlin, Germany1421-7.

[101] Ranalli, G.; Chiavarini, M.; Guidetti, V. The use of microorganism for the removal of sulphates on artistic stoneworks. Int. Biodeterior. Biodegradation, 1997, 40, 255-261. [http://dx.doi.org/10.1016/S0964-8305(97)00054-1]

[102] Alfano, G.; Lustrato, G.; Belli, C. The bioremoval of nitrate and sulfate alterations on artistic stonework: The case study of Matera Cathedral after six years from the treatment. Int. Biodeterior. Biodegradation, 2011, 65, 1004-1011. [http://dx.doi.org/10.1016/j.ibiod.2011.07.010]

[103] Valentini, F.; Diamanti, A.; Palleschi, G. New bio cleaning strategies on porous building materials affected by biodeterioration event. Appl. Surf. Sci., 2010, 256, 6550-6563.

[http://dx.doi.org/10.1016/j.apsusc.2010.04.046]

[104] Valentini, F.; Diamanti, A.; Carbone, M.; Bauer, E.M.; Palleschi, G. New cleaning strategies based on carbon nanomaterials applied to the deteriorated marble surfaces: A comparative study with enzyme based treatments. Appl. Surf. Sci., 2012, 258, 5965-5980. [http://dx.doi.org/10.1016/j.apsusc.2012.01.076]

[105] Webster, A.; May, E. Bioremediation of weathered building stone surfaces. Trends Biotechnol., 2006, 24(6), $255-260$. [http://dx.doi.org/10.1016/j.tibtech.2006.04.005] [PMID: 16647149]

[106] Troiano, F.; Gulotta, D.; Balloi, A. Successful combination of chemical and biological treatments for the cleaning of stone artworks. Int. Biodeterior. Biodegradation, 2013, 85, 294-304. [http://dx.doi.org/10.1016/j.ibiod.2013.08.011]

[107] Patrauchan, M.A.; Oriel, P.J. Degradation of benzyldimethylalkylammonium chloride by Aeromonas hydrophila sp. K. J. Appl. Microbiol., 2003, 94(2), 266-272. [http://dx.doi.org/10.1046/j.1365-2672.2003.01829.x] [PMID: 12534818]

[108] Houari, A.; Di Martino, P. Effect of chlorhexidine and benzalkonium chloride on bacterial biofilm formation. Lett. Appl. Microbiol., 2007, $45(6), 652-656$ 
[http://dx.doi.org/10.1111/j.1472-765X.2007.02249.x] [PMID: 17944843]

[109] Gazzano, C.; Favero-Longo, S.E.; Iacomussi, P.; Piervittori, R. Biocidal effect of lichen secondary metabolites against rock dwelling microcolonial fungi, cyanobacteria and green algae. Int. Biodeterior. Biodegradation, 2013, 84, 300-306. [http://dx.doi.org/10.1016/j.ibiod.2012.05.033]

[110] Elix, J.A.; Stocker-Wörgötter, E. Biochemistry and secondary metabolites. In: Lichen Biology, $2^{\text {nd }}$ ed; Nash, T.H., III, Ed.; Cambridge University Press: UK, 2008; pp. 104-133. [http://dx.doi.org/10.1017/CBO9780511790478.008]

Received: June 15, 2015

Revised: June 25, 2015

Accepted: July 31, 2015

(C) Patrick D. Martino; Licensee Bentham Open.

This is an open access article licensed under the terms of the Creative Commons Attribution-Non-Commercial 4.0 International Public License (CC BY-NC 4.0) (https://creativecommons.org/licenses/by-nc/4.0/legalcode), which permits unrestricted, non-commercial use, distribution and reproduction in any medium, provided the work is properly cited. 